\title{
Relationships between pigment ratios and growth irradiance in 11 marine phytoplankton species
}

\author{
Martin Laviale ${ }^{1,2}$, Jacques Neveux ${ }^{1, *}$ \\ ${ }^{1}$ CNRS-Université Pierre et Marie Curie, Laboratoire d'Océanographie Microbienne (LOMIC, UMR 7621), Avenue Fontaulé, \\ 66651 Banyuls sur Mer, France \\ ${ }^{2}$ Present address: Laboratoire Mer, Molécules, Santé, UPRES-EA 2160, Université de Nantes, 2 rue de la Houssinière, \\ BP 92208, Nantes Cedex 03, France
}

\begin{abstract}
Light-dependent variation in pigment content was examined in 11 marine phytoplankton species representing 8 algal classes. Batch cultures of each species were acclimated to 7 irradiances between 10 and $700 \mu \mathrm{mol}$ photons $\mathrm{m}^{-2} \mathrm{~s}^{-1}$. High-performance liquid chromatography analysis on exponentially growing cultures revealed that pigment ratios normalised to chlorophyll $a$ (chl $a$ ) generally fell within the ranges previously reported for species of the same taxa. Unambiguous lightharvesting pigments (e.g. chlorophylls, fucoxanthin) showed limited amplitude of variation between low and high light conditions, while those involved in photoprotection (e.g. zeaxanthin, lutein, alloxanthin, diatoxanthin) dramatically increased under high light. Most of the relationships between pigment:chl a ratios and growth irradiance were quite well described using simple linear models. Among pigments shared by several species, chl $b$ and $c_{3}$, fucoxanthin, zeaxanthin, lutein, diadinoxanthin and diatoxanthin exhibited similar trends regardless of the species studied, allowing general equations to be determined for each of these pigments. Determination of light:pigment relationships is a prerequisite for the development of more advanced modeling techniques such as artificial neural networks in chemotaxonomic studies.
\end{abstract}

KEY WORDS: Phytoplankton $\cdot$ Cultures $\cdot$ Pigment ratios $\cdot$ Irradiance $\cdot$ Regression analysis $\cdot$ HPLC

\section{INTRODUCTION}

Phytoplankton accounts for only 1 to $2 \%$ of the total photosynthetic carbon biomass but contributes to approximately $45 \%$ of primary production on Earth (Field et al. 1998). It is well established that its composition greatly influences the functional structure and productivity of the whole pelagic food web (Fenchel 1988). Therefore, a better understanding of the global biogeochemical processes involved in climate change relies on a good knowledge of phytoplankton composition and dynamics at a local scale (Falkowski et al. 1998). Basically, the routine determination of phytoplankton composition and abundance in oceanographic studies is based on 3 main approaches: (1) microscopic observations enable taxonomic identification down to the species level but are time consum- ing and not always feasible for small or fragile cells (flagellates) that do not support fixatives (Sournia 1978); (2) pigment analyses (chemotaxonomic approach) by reversed-phase high-performance liquid chromatography (HPLC) provide reliable quantitative estimates that are generally related to a class level (e.g. diatoms), but sometimes more precisely to a group of species inside a class (e.g. different types of haptophytes) or exceptionally to a genus (i.e. Prochlorococcus; Jeffrey \& Vesk 1997); (3) genetic tools associated with flow cytometric methods are useful to study the diversity of picoplankton but are still limited by the number of taxonomic groups that are well represented by isolated cultures (e.g. picoprasinophytes; Guillou et al. 2004, Shi et al. 2009). Several studies combining these complementary approaches have considerably advanced our general understanding of 
phytoplankton ecology at various temporal and spatial scales (Simon et al. 2009). An unsuspected diversity has been revealed, in particular in the picoplanktonic size fraction, even sometimes at the intraspecific level (e.g. Rodriguez et al. 2005, Liu et al. 2009).

The chemotaxonomic approach relies on the quantitative measurement of total chlorophyll $a$ (Tchl a) as a proxy of phytoplankton biomass and of accessory pigments (other chlorophylls, carotenoids) as more or less specific chemotaxonomic markers. The contributions of distinct groups of microalgae to Tchl a can then be inferred from accessory pigment to Tchl a ratios (Jeffrey et al. 1999). A limited number of pigments can be assigned unambiguously to an algal class (e.g. alloxanthin for Cryptophyceae, but see Lewin et al. 2000) or exceptionally to a genus (i.e. divinyl-chl a for Procholorococcus, which in field studies is also included in Tchl a estimates). On the other hand, some pigments are distributed across several classes (e.g. fucoxanthin in Bacillariophyceae, Chrysophyceae, Dinophyceae and Prymnesiophyceae) or shared by groups of species without correspondence with conventional taxa (e.g. 19'hexanoylfucoxanthin in some Haptophyceae and Dinophyceae) (Jeffrey \& Vesk 1997). Along with this qualitative variability, it is well documented that pigment concentrations can also change with the physiological state of the cells, thereby explaining quantitative intraclass differences between species as well as between clones of the same species (Falkowski \& Raven 1997).

As a result, interpreting pigment data remains a complex problem to be solved. Several computational methods have been proposed (see Jeffrey et al. 1999 for review), among which the CHEMTAX software has been extensively used in various oceanic regions (e.g. Wright et al. 1996, Mackey et al. 2002, Llewellyn et al. 2005) since its publication (Mackey et al. 1996). This matrix factorisation program compares the distribution of the pigment to chl a ratios (pigment:chl $a$ ) of the natural sample with a reference dataset which is built from literature values, with pigment ratios representative of the algal groups to be determined (Mackey et al. 1996). The user must define the most complete reference dataset in order to improve the accuracy of the estimation. Therefore, there is a need for empirical pigment measurements on individual species, in particular to appreciate intraclass variability in pigment composition and pigment ratios of different species cultured under the same conditions (e.g. Stauber \& Jeffrey 1988, Latasa et al. 2004, Zapata et al. 2004, LazaMartinez et al. 2007) and how environmental changes and cell physiology can affect them. Comprehensive studies have already pointed out the influence of the growth phase of the cells and the culture conditions such as temperature, nutrient status and light regime on the pigment:chl a ratios (e.g. Goericke \& Montoya 1998, Llewellyn \& Gibb 2000, Schlüter et al. 2000, Henriksen et al. 2002, Rodriguez et al. 2006, Seoane et al. 2009). More precisely, the existing literature investigating the light effect is usually focused on a limited number of light conditions (Schlüter et al. 2000, Rodriguez et al. 2006, Seoane et al. 2009), pigments (Fujiki \& Taguchi 2002) and/or species (MacIntyre et al. 2002, Six et al. 2004, 2008, Leonardos \& Harris 2006). According to a previous review on photoacclimation of several algae (MacIntyre et al. 2002), the decline of the chl a content in response to increasing irradiance is common and accompanied by a decrease of the accessory chlorophyll concentrations, so that the accessory chlorophyll:chl a ratios vary little as long as the light is limiting. These ratios tend to dramatically decrease by 80 to $90 \%$ above the growth light saturation limit (MacIntyre et al. 2002). Furthermore, photosynthetic carotenoids show contrasting variation patterns with light intensity while photoprotective carotenoids accumulate at high irradiance (MacIntyre et al. 2002). To date, the relationships linking individual pigments and irradiance remain to be mathematically formulated in various representative phytoplanktonic organisms (Leonardos \& Harris 2006). The comparison of the shape and magnitude of the obtained curves would provide a convenient way to determine to what extent the physiological processes underlying photoacclimation rely on pigment-specific or species-specific patterns of change.

In this context, we investigated the light-dependent variation in the pigment content of 11 species representing 8 marine phytoplankton classes. Species were acclimated to 7 levels over a wide growth irradiance range (10 to $700 \mu \mathrm{mol}$ photons $\mathrm{m}^{-2} \mathrm{~s}^{-1}$ ). This range matched most of irradiances observed in the euphotic zone but did not include extreme values of high insolation experienced in the upper layer (2000 to $3000 \mu \mathrm{mol}$ photons $\mathrm{m}^{-2} \mathrm{~s}^{-1}$ at noon). This paper reports the range of variation of different pigment ratios for abundant and well-known as well as rarely described pigments (e.g. uriolide:chl $a_{1} \operatorname{chl} c_{3}: \operatorname{chl} c_{2}$ ). The data were analysed to test whether simple linear models are suitable for describing the relationships between irradiance and those ratios. The possible use of this data set to develop new statistical methods in determination of the taxonomic composition of algal communities is also discussed.

\section{MATERIALS AND METHODS}

Organisms and culture conditions. Eleven species representing 8 classes of marine phytoplankton were obtained from the Roscoff Culture Collection (RCC, 
Roscoff, France: Vaulot et al. 2004; Table 1). These species were selected to illustrate both intra- and interclass pigment signature variability using ecologically relevant taxa. They were grown at $16^{\circ} \mathrm{C}$ as non axenic batch cultures in $200 \mathrm{ml}$ glass flasks containing $100 \mathrm{ml}$ of K medium (Keller et al. 1987), except for Synechococcus sp., which was cultivated in $\mathrm{f} / 2$ medium (Guillard \& Ryther 1962). One sample of each species was cultivated at 7 irradiance levels ranging from 10 to $700 \mu \mathrm{mol}$ photons $\mathrm{m}^{-2} \mathrm{~s}^{-1}$ in a 12:12 h light:dark cycle. The light gradient was adjusted by positioning the flasks more or less close to the continuous light source which was provided by a bank of 6 cool-white fluorescent tubes (Philips TL-D 18W/965). Irradiances were measured directly in front of the culture flasks by means of a QSL100 photosynthetically active radiation (PAR) sensor with a $4 \pi$ probe (Biospherical Instruments). Measurements carried out inside flasks filled with culture medium did not give significantly different values. To ensure complete photoacclimation, each culture was maintained in this light gradient for at least $15 \mathrm{~d}$ in exponential growth phase by diluting $2 \mathrm{ml}$ of the semicontinuous batch culture in fresh medium as soon as slight colouration was visible to the naked eye. This regular dilution enabled us to keep relatively low cell densities and minimise the self-shading effect on cell pigment characteristics. Furthermore, flasks were shaken by hand every 2 to $4 \mathrm{~h}$ during the light period.

Cell counts. For all species but Skeletonema costatum, $1 \mathrm{ml}$ culture samples were collected in $1.2 \mathrm{ml}$ Nunc cryotubes. They were preserved by a $20 \mu \mathrm{l}$ addition of $10 \%$ paraformaldehyde solution (final concentration: $0.2 \%$, Campbell \& Vaulot 1993) and then frozen in liquid nitrogen. Thawed samples were analysed between 15 and $30 \mathrm{~d}$ after sampling with a FACSCan flow cytometer (BD-Biosciences). For each sample, light scatter at forward (FALS) and right angle (RALS), orange and red fluorescence cellular proper- ties and cell counts were determined. Data were normalised using fluorescent $0.95 \mu \mathrm{m}$ (Polysciences) and $8.69 \mu \mathrm{m}$ (Epics, Beckman Coulter) beads. Cell counts of the chain-forming $S$. costatum were performed on fixed samples at 200× magnification using an inverted microscope and a Malassez counting chamber (at least 100 cells counted, in triplicates).

Pigment analyses. Two subsamples for each culture were collected by filtering variable volumes (25 to $50 \mathrm{ml}$ ) depending on the culture cell density onto $25 \mathrm{~mm}$ Whatman GF/F glass fibre filters which were immediately frozen and stored in liquid nitrogen until pigment extraction. Chlorophylls and carotenoids were analysed within 2 wk by HPLC. For extracting the pigments, filters were thawed, ground with a sharpened glass rod and then left overnight at $+4^{\circ} \mathrm{C}$ in glass tubes containing $4.85 \mathrm{ml}$ of $93 \%$ acetone resulting in a nominal concentration of $90 \%$ acetone due to water contained in the filter. The extracts were centrifuged at $800 \times g(6 \mathrm{~min})$. Supernatants were filtered with PTFE membranes (thickness $=0.2 \mu \mathrm{m}$, diameter $=$ $13 \mathrm{~mm}$; Uptidisc) to remove residual cell and filter debris. To improve the sharpness of peaks, the extracts were automatically diluted with water to $70 \%$ acetone after transferring them in HPLC vials (Interchrom) placed in a Gilson cooling $\left(+4^{\circ} \mathrm{C}\right)$ autosampler. Sample volumes of $200 \mu \mathrm{l}$ were automatically injected into the HPLC system, and pigment separation was realised on a temperature controlled $\left(+25^{\circ} \mathrm{C}\right) \mathrm{C}_{8}$ reverse phase column (Uptisphere, $150 \times 4.6 \mathrm{~mm}, 3 \mu \mathrm{m}$ particle size). After separation following the method of Zapata et al. (2000), pigments were detected by using a Gynkotek system equipped with a UVD 340 S photodiode array detector (Dionex). Pigments were identified by their retention time and absorption spectra in comparison with those given in the literature (Jeffrey et al. 1997, Zapata et al. 2000) and external standards supplied by DHI Water and Environment (Hørsholm, Denmark).

Table 1. Marine phytoplankton species studied. RCC: Roscoff Culture Collection (France)

\begin{tabular}{|lllr}
\hline Taxon & Class & Species & RCC no. \\
\hline Cyanophyta & Cyanophyceae & Synechococcus sp. Nägli & 30 \\
Chlorophyta & Chlorophyceae & Dunaliella tertiolecta Butcher & 6 \\
& Prasinophyceae & Micromonas pusilla (Butcher) Manton et Parke & 372 \\
& & Ostreococcus tauri Courties and Chrétiennot-Dinet & 116 \\
& & Pycnococcus sp. Guillard & 245 \\
Cryptophyta & Cryptophyceae & Rhodomonas baltica Karsten & 350 \\
Haptophyta & Coccolithophyceae & Prymnesium parvum f. patelliferum (Green, Hibberd and & 191 \\
& (former class Prymnesio- & Pienaar) Larsen (according to Larsen 1999) & \\
& phyceae (Silva et al. 2007) & Pleurochrysis pseudoroscoffensis Gayral and Fresnel & \\
Dinophyta & Dinophyceae & Prorocentrum minimum (Pavillard) Schiller & 703 \\
Ochrophyta & Bacillariophyceae & Skeletonema cf. costatum (Greville) Cleve & \\
& Dictyochophyceae & Florenciella parvula Eikrem & \\
& & &
\end{tabular}


Pigments were then quantified close to their absorption maxima $(410,440,450$ or $460 \mathrm{~nm})$ by peak area calculations using extinction coefficients cited by Jeffrey (1997).

Data presented are cellular chl a content (pg cell ${ }^{-1}$ ) and weight to weight pigment ratios $\left(\mathrm{g} \mathrm{g}^{-1}\right)$. In particular, the xanthophyll cycle de-epoxidation ratio (DR) was calculated to illustrate the light-induced accumulation of some photoprotective carotenoids (Brunet et al. 2011). In the diatom (Skeletonema costatum), the 2 haptophytes (Prymnesium parvum and Pleurochrysis pseudoroscoffensis), the dinophyte (Prorocentrum minimum) and the Dictyochophyceae (Florenciella parvula), the cycle consists of the 1-step enzymatic deepoxidation of diadinoxanthin (DD) into diatoxanthin (DT):

$$
\mathrm{DR}=\mathrm{DT} /(\mathrm{DD}+\mathrm{DT})
$$

In the chlorophytes (Dunaliella tertiolecta, Ostreococcus tauri, Micromonas pusilla and Pycnococcus sp.) this cycle implies a 2-step de-epoxidation of violaxanthin $(\mathrm{V})$ into zeaxanthin $(\mathrm{Z})$ via antheraxanthin $(\mathrm{A})$ :

$$
\mathrm{DR}=\mathrm{Z} /(\mathrm{V}+\mathrm{A}+\mathrm{Z})
$$

Statistical analysis. For each pigment quantified, the relationship between the cellular chl a content or other pigment ratio $(Y)$ and the irradiance $(X)$ was determined by fitting the data ( $\mathrm{n}=7$ for each analysis, each point being the mean of 2 subsamples) to the following mathematical functions:

$$
\begin{gathered}
Y=a+b X \\
Y=a \times \log (b X) \\
Y=a \times \exp (b X) \\
Y=a X^{b}
\end{gathered}
$$

In these simple 2-parameter models, $a$ is the intercept and $b$ is the regression slope. The models are referenced hereafter as 'linear', 'logistic', 'exponential' and 'power', respectively. They are linear (Eq. 3) or easily linearised as follows:

$$
\begin{gathered}
\exp (Y)=\exp (a)+b X \\
\log (Y)=\log (a)+b X \\
\log (Y)=\log (a)+b \times \log (X)
\end{gathered}
$$

After the appropriate transformation, linear regressions were conducted using the $\mathrm{R}$ statistical computing environment (v 2.8.1, Ihaka \& Gentleman 1996). To take into account the limited number of data $(n=7)$, analyses were performed using a robust least square fitting (rlm function from the MASS library), which minimises the influence of potential outliers (Crawley 2007).
After checking data normality and homoscedasticity using the residuals, only regression coefficients at the $95 \%$ level were considered statistically significant.

For the cellular chl a content and some marker pigments, data from individual species were pooled and a 2-way analysis of variance (ANOVA) was used with 'species' and 'irradiance' defined as fixed factors. Finally, the statistical TableCurve 2D software (v. 4.07, SPSS) was used to determine the best-fit equation describing these data, and the determination coefficient $\left(\mathrm{R}^{2}\right)$ and the statistical significance of the relative slope (b) estimated were then compared to those obtained for the different linear models.

\section{RESULTS}

\section{Pigment composition}

\begin{tabular}{|c|c|c|c|c|}
\hline $\begin{array}{l}\text { Peak } \\
\text { no. }\end{array}$ & Pigment & Abbreviation & $\begin{array}{l}\text { Retention } \\
\text { time }\end{array}$ & $\lambda_{\mathrm{abs}}$ \\
\hline 1 & Chlorophyll $C_{3}$ & $\mathrm{Chl} C_{3}$ & 8.48 & 460 \\
\hline 2 & Chlorophyllide $a$ & Chlide $a$ & 10.30 & 410 \\
\hline 3 & $\begin{array}{l}\text { Mg-2,4-divinyl pheopor- } \\
\text { phyrin a5 monomethylester }\end{array}$ & MgDVP & 11.09 & 440 \\
\hline 4 & Chlorophyll $C_{2}$ & $\mathrm{Chl} C_{2}$ & 11.60 & 450 \\
\hline 5 & Chlorophyll $c_{1}$ & $\mathrm{Chl} c_{1}$ & 12.33 & 450 \\
\hline 6 & Peridinin & Peri & 14.95 & 460 \\
\hline 7 & Uriolide & Uri & 18.11 & 450 \\
\hline 8 & 19'-Butanoyloxyfucoxanthin & But-fuco & 18.22 & 450 \\
\hline 9 & Fucoxanthin & Fuco & 19.50 & 450 \\
\hline 10 & Neoxanthin & Neo & 19.81 & 440 \\
\hline 11 & Prasinoxanthin & Pras & 21.25 & 460 \\
\hline 12 & Violaxanthin & $\mathrm{V}$ & 21.96 & 440 \\
\hline 13 & Diadinoxanthin & $\mathrm{DD}$ & 24.63 & 450 \\
\hline 14 & Dinoxanthin & Dino & 25.73 & 440 \\
\hline 15 & Antheraxanthin & A & 26.05 & 450 \\
\hline 16 & Alloxanthin & Allo & 26.78 & 450 \\
\hline 17 & Diatoxanthin & DT & 27.68 & 450 \\
\hline 18 & Monadoxanthin & Monado & 27.69 & 450 \\
\hline 19 & Zeaxanthin & Z & 28.39 & 450 \\
\hline 20 & Lutein & Lut & 28.42 & 450 \\
\hline 21 & Dihydrolutein & Dihy & 28.83 & 440 \\
\hline 22 & Crocoxanthin & Croco & 31.91 & 450 \\
\hline 23 & Chlorophyll $b$ & Chl $b$ & 32.35 & 460 \\
\hline 24 & Chlorophyll a & Chl a & 33.78 & 410 \\
\hline 25 & $\beta, \psi$-Carotene & $\gamma$-car & 35.27 & 460 \\
\hline 26 & $\beta, \varepsilon$-Carotene & $\alpha$-car & 36.59 & 450 \\
\hline 27 & $\beta, \beta$-Carotene & $\beta$-car & 36.81 & 450 \\
\hline
\end{tabular}

The 27 liposoluble pigments identified from the 11 phytoplanktonic species and the corresponding abbreviations used in the following text are listed in Table 2. The chosen method (Zapata et al. 2000) allowed us to clearly separate the different chlorophylls $C$ and some

Table 2. Chromatographic retention times (in $\min$ ) and wavelength detection $\left(\lambda_{\text {abs }}\right.$ in $\mathrm{nm}$ ) used for quantification (area integration) of the 27 pigments identified. Abbreviations used throughout the text are given 
of their derivatives ( $\mathrm{chl} \boldsymbol{C}_{1}, C_{2}, C_{3}$ and the chl $c$-like pigment MgDVP in particular). All chl $\mathrm{C}$-containing species (Rhodomonas baltica, Prymnesium parvum, Pleurochrysis pseudoroscoffensis, Prorocentrum minimum, Skeletonema costatum and Florenciella parvula) shared chl $C_{2}$, whereas chl $c_{1}$ was present only in the 2 haptophytes and the diatom, and chl $c_{3}$ was only present in F. parvula and $P$. parvum. MgDVP was detected only in the 3 Prasinophyceae. A significant amount of Chlide a was measured in S. costatum (around $80 \%$ of the total chl a) and to a smaller extent $(<10 \%)$ in Dunaliella tertiolecta. As all cultures were collected in exponential growth phase (i.e. cells were not senescent), the accumulation of this chl a hydrolysis product was probably linked to a high activity of the chlorophyllase in these 2 species during the filtration or/and extraction processes (Neveux 1988). The extraction of the second subsample of S. costatum in $95 \%$ instead of $90 \%$ acetone significantly reduced (around 50\%) the degradation of chl $a$ to Chlide $a$ in most of the samples. This methodological artefact was taken into account in the following results by adding the amount of Chlide $a$ to chl $a$, thereby preventing underestimation of chl $a$ and overestimation of the pigment:chl a ratios.

Regarding xanthophylls, some co-eluting pigments were not fully resolved, viz. Lut and Z (in the chlorophytes) and $\alpha$-car and $\beta$-car (in Prymnesium parvum and Dunaliella tertiolecta). The most common pigment was $\beta$-car, which was found in 10 species regardless of the light conditions, whereas it was replaced by $\alpha$-car in Rhodomonas baltica. The 3 Prasinophyceae shared the major carotenoid Prasino and the minor carotenoid Dihy. They differed by the presence of Uri and an unidentified carotene (eluting before $\beta$-car) only in Ostreococcus tauri and Micromonas pusilla. The Dictyochophyceae Florenciella parvula was specifically characterised by the presence of But-fuco and $\mathrm{Z}$, the latter being detected in cultures grown at irradiances $\geq 175 \mu \mathrm{mol}$ photons $\mathrm{m}^{-2} \mathrm{~s}^{-1}$.

Table 3. Cellular chl a (mean of 2 subsamples in pg cell ${ }^{-1}$ ) of 11 phytoplankton species photacclimated to each of 7 levels of irradiance (10 to $700 \mu \mathrm{mol}$ photons $\mathrm{m}^{-2} \mathrm{~s}^{-1}$ ). ng: no growth. Full species names are given in Table 1

\begin{tabular}{|lccccccc|}
\hline \multirow{2}{*}{ Species } & \multicolumn{8}{c|}{ Irradiance $\left(\mu \mathrm{mol}\right.$ photons $\left.\mathrm{m}^{-2} \mathrm{~s}^{-1}\right)$} & \\
\cline { 2 - 8 } & 10 & 20 & 40 & 80 & 175 & 350 & 700 \\
\hline S. costatum & 1.33 & 1.74 & 1.51 & 1.14 & 0.78 & 0.64 & 0.52 \\
P. minutum & $\mathrm{ng}$ & $\mathrm{ng}$ & 10.3 & 4.84 & 2.75 & 1.97 & 2.15 \\
R. baltica & 5.44 & 3.58 & 3.84 & 3.34 & 1.84 & 1.74 & 1.08 \\
M. pusilla & 0.105 & 0.090 & 0.066 & 0.060 & 0.063 & 0.034 & 0.018 \\
P. parvum & 2.59 & 1.89 & 0.84 & 0.45 & 0.28 & 0.18 & 0.14 \\
D. tertiolecta & 4.53 & 2.95 & 3.10 & 1.98 & 1.83 & 1.26 & 1.10 \\
Synechococcus sp. & 0.0047 & 0.0031 & 0.0023 & 0.0025 & 0.0016 & 0.0016 & 0.0012 \\
O. tauri & 0.019 & 0.018 & 0.011 & 0.010 & 0.0084 & 0.0053 & 0.0046 \\
F. parvula & 0.30 & 0.30 & 0.25 & 0.24 & 0.18 & 0.14 & 0.076 \\
Pycnococcus sp. & 0.59 & 0.59 & 0.53 & 0.32 & 0.28 & 0.25 & 0.21 \\
P. pseudoroscoffensis & 9.17 & 6.54 & 6.07 & 3.64 & 3.44 & 1.86 & 1.64 \\
\hline
\end{tabular}

\section{Effect of light on cellular chl a content and pigment ratios}

Each species exhibited a significant reduction in the cellular chl a content with increasing irradiance (Table 3, linear regression analyses: $0.88 \leq \mathrm{R}^{2} \leq 0.98$ ). The 2 way ANOVA performed on standardised and pooled data ( $\mathrm{n}=82$, Fig. 1 ) showed that the response to growth irradiance was comparable between species ( $p=0.59$ ), which is illustrated by the well fitted 2-parameter logistic model which was determined using the software TableCurve $\left(Y=-0.609 \ln X+2.7228, \mathrm{R}^{2}=\right.$ $0.87, \mathrm{p}<0.001)$. The pigment:chl a ratios obtained for each species at each irradiance are presented in Table 4.

\section{Chlorophylls}

The chl $b$ :chl a ratio exhibited a slight (21 to $39 \%$ of variation) but significant decrease (regression analysis: $\mathrm{p}<0.01$ ) when irradiance increased in all chl $b$ containing species (Dunaliella tertiolecta, Micromonas pusilla, Ostreococcus tauri and Pycnococcus sp.). The mean ratio was lower for $D$. tertiolecta $(0.220 \pm 0.024)$ than for the Prasinophyceae $(0.677 \pm 0.159)$. The MgDVP:chl a mean ratio was comparable in the 3 Prasinophyceae $(0.032 \pm 0.010)$. However, this ratio responded differently to the light increase among species: it remained stable in $O$. tauri $(\mathrm{p}>0.1)$ whereas it significantly increased in M. pusilla $(+108 \%, \mathrm{p}<0.01)$ and decreased in Pycnococcus sp. $(-39 \%, \mathrm{p}<0.01)$.

For chl $c$-containing species, the mean total pool of chlorophylls $c$ (Tchl $c$ ) normalised to chl a was higher in Florenciella parvula $(0.215 \pm 0.036)$ and Prorocentrum minimum $(0.207 \pm 0.016)$ than in Prymnesium parvum $(0.135 \pm 0.050)$, Skeletonema costatum (0.098 \pm 0.018), Rhodomonas baltica (0.078 \pm 0.008) and Pleurochrysis pseudoroscoffensis $(0.077 \pm 0.018)$. This ratio globally decreased with increasing irradiance ( $p<0.05$, Fig. 2). In species containing several chlorophylls $c_{\text {, }}$ the chl $C_{2}$ :chl a ratio described a 3 -fold decrease in $P$. parvum ( $\mathrm{p}<0.01)$, S. costatum $(\mathrm{p}<0.001)$ and $P$. pseudoroscoffensis ( $\mathrm{p}<0.01)$, whereas it remained nearly constant in $F$. parvula ( $\mathrm{p}>0.10$, Table 4). In $P$. parvum, the chl $c_{1}$ :chl $C_{2}$ and chl $C_{3}$ :chl $C_{2}$ ratios were not correlated with irradiance $(\mathrm{p}>0.12)$ due to the fact that $\operatorname{chl} C_{1}, C_{2}$ and $C_{3}$ decreased similarly (Fig. 2). In contrast, the chl $C_{1}: \operatorname{chl~} C_{2}$ (or chl $C_{3}: \operatorname{chl~} C_{2}$ 


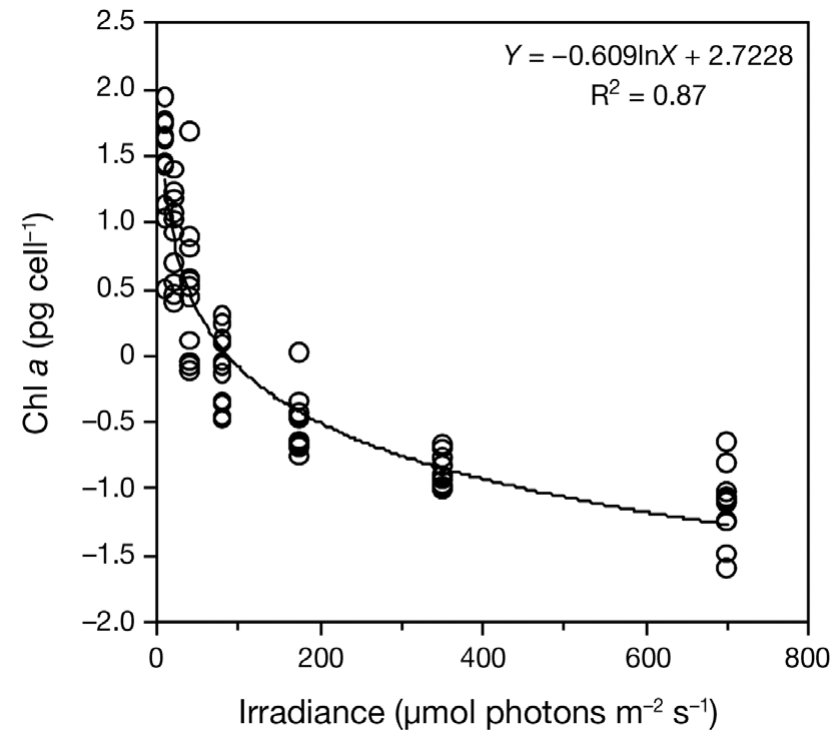

Fig. 1. Variation of the cellular chl a content (mean of 2 subsamples, in $\mathrm{pg} \mathrm{cell}^{-1}$ ) in 11 species photoacclimated to 7 levels of irradiance (10 to $700 \mu \mathrm{mol}$ photons $\left.\mathrm{m}^{-2} \mathrm{~s}^{-1}\right)$. Data from individual species (Table 3) were first standardised and then pooled. The solid line indicates the best fitted equation in F. parvula) ratios co-varied with irradiance for the other species ( $\mathrm{p}<0.01$ or $\mathrm{p}<0.05$ for $F$. parvula), suggesting species-specific patterns of variation for the different chlorophylls $c$.

\section{Carotenoids}

Several xanthophyll:chl a ratios decreased significantly with increasing irradiance. This was the case for Fuco in the 2 haptophytes (around $-30 \%, \mathrm{p}<0.01$ ) and Skeletonema costatum $(-13 \%, \mathrm{p}<0.05)$ and the minor pigments Monado $(-52 \%, \mathrm{p}<0.01)$ and Croco $(-19 \%$, $\mathrm{p}<0.01)$ in Rhodomonas baltica. In Florenciella parvula, Fuco and But-fuco exhibited opposite patterns $(-30 \%$ and $+38 \%$ of variation, respectively, $p<0.01)$, resulting in a total pool of Fuco which was not significantly affected by the growth irradiance $(p>0.10)$. The pattern was less clear for the chl $b$-containing species. Prasino showed a mean chl a-normalised value 2-fold higher in Pycnococcus sp. $(0.301 \pm 0.024)$ than in Micromonas pusilla $(0.139 \pm 0.015)$, and an intermediate value in Ostreococcus tauri $(0.201 \pm 0.014)$. The

Table 4. Chl a-normalised pigment ratios $\left(\mathrm{g} \mathrm{g}^{-1}\right)$ for 11 phytoplankton species. The ratio obtained for each of the 7 levels of irradiance (mean of 2 subsamples), the mean value ( \pm SD) and the variation (Var) of the ratio (\%) between low and high light conditions (10 and $700 \mu \mathrm{mol}$ photons $\mathrm{m}^{-2} \mathrm{~s}^{-1}$ ) are indicated for each pigment. Based on the regression analysis (see Supplement 1 at www.int-res.com/articles/suppl/m425p063_supp.pdf for details), values in bold indicate that the light-dependent trend was not significant for the pigment studied. ng: no growth; nd: not detected; na: data not available. Full species names are given in Table 1, and full pigment names in Table 2

\begin{tabular}{|c|c|c|c|c|c|c|c|c|c|c|}
\hline \multirow[t]{2}{*}{ Species } & \multirow[t]{2}{*}{ Pigment:chl $a$} & \multicolumn{7}{|c|}{ Irradiance $\left(\mu \mathrm{mol}\right.$ photons $\left.\mathrm{m}^{-2} \mathrm{~s}^{-1}\right)$} & \multirow[t]{2}{*}{ Mean \pm SD } & \multirow[t]{2}{*}{ Var } \\
\hline & & 10 & 20 & 40 & 80 & $175 \mathrm{i}$ & 350 & 700 & & \\
\hline \multirow[t]{2}{*}{ Synechococcus sp. } & $\beta$-car & 0.124 & 0.128 & 0.119 & 0.105 & 0.078 & 0.076 & na & $0.105 \pm 0.023$ & -39 \\
\hline & Z & 0.781 & 0.883 & 1.007 & 0.945 & 1.041 & 1.216 & 1.680 & $1.079 \pm 0.298$ & 115 \\
\hline \multirow[t]{9}{*}{ D. tertiolecta } & Chl $b$ & 0.255 & 0.245 & 0.230 & 0.219 & 0.197 & 0.192 & 0.202 & $0.220 \pm 0.024$ & -21 \\
\hline & A & 0.005 & 0.004 & 0.005 & 0.007 & 0.031 & 0.018 & 0.037 & $0.015 \pm 0.014$ & 640 \\
\hline & $\alpha$-car & 0.004 & 0.002 & 0.003 & 0.004 & 0.002 & 0.003 & nd & $0.003 \pm 0.001$ & \\
\hline & $\beta$-car & 0.064 & 0.059 & 0.057 & 0.063 & 0.074 & 0.075 & 0.068 & $0.066 \pm 0.007$ & 6 \\
\hline & $\gamma$-car & 0.023 & 0.014 & 0.014 & 0.014 & 0.024 & 0.026 & 0.010 & $0.018 \pm 0.006$ & -57 \\
\hline & Lut & 0.149 & 0.141 & 0.151 & 0.171 & 0.190 & 0.215 & 0.255 & $0.182 \pm 0.041$ & 71 \\
\hline & $\mathrm{Neo}$ & 0.021 & 0.015 & 0.025 & 0.029 & 0.032 & 0.033 & 0.033 & $0.027 \pm 0.007$ & 57 \\
\hline & $\mathrm{V}$ & 0.043 & 0.035 & 0.052 & 0.059 & 0.049 & 0.009 & 0.012 & $0.037 \pm 0.020$ & -72 \\
\hline & $\mathrm{Z}$ & nd & nd & nd & nd & 0.025 & 0.113 & 0.150 & $0.096 \pm 0.064$ & \\
\hline \multirow[t]{10}{*}{ M. pusilla } & Chl b & 0.802 & 0.778 & 0.767 & 0.732 & 0.684 & 0.549 & 0.490 & $0.686 \pm 0.121$ & -39 \\
\hline & MgDVP & 0.013 & 0.017 & 0.022 & 0.020 & 0.028 & 0.025 & 0.027 & $0.022 \pm 0.005$ & 108 \\
\hline & $\beta$-car & 0.028 & 0.025 & 0.015 & 0.038 & 0.049 & 0.069 & 0.075 & $0.043 \pm 0.023$ & 168 \\
\hline & Dihy & 0.073 & 0.054 & 0.064 & 0.086 & 0.077 & 0.061 & 0.047 & $0.066 \pm 0.014$ & -36 \\
\hline & Lut & nd & nd & 0.005 & 0.008 & 0.015 & 0.066 & 0.113 & $0.041 \pm 0.047$ & \\
\hline & Neo & 0.067 & 0.051 & 0.056 & 0.06 & 0.06 & 0.047 & 0.044 & $0.055 \pm 0.008$ & -34 \\
\hline & Prasino & 0.201 & 0.182 & 0.190 & 0.217 & 0.203 & 0.219 & 0.192 & $0.201 \pm 0.014$ & -4 \\
\hline & Uri & 0.025 & 0.025 & 0.020 & 0.012 & 0.013 & 0.012 & 0.040 & $0.021 \pm 0.010$ & 60 \\
\hline & $\mathrm{V}$ & 0.037 & 0.033 & 0.034 & 0.072 & 0.088 & 0.187 & 0.176 & $0.090 \pm 0.066$ & 376 \\
\hline & $\mathrm{Z}$ & nd & nd & 0.005 & 0.007 & 0.012 & 0.020 & 0.036 & $0.016 \pm 0.013$ & \\
\hline \multirow[t]{3}{*}{ O. tauri } & Chl $b$ & 0.560 & 0.528 & 0.542 & 0.527 & 0.499 & na & 0.438 & $0.516 \pm 0.043$ & -22 \\
\hline & MgDVP & 0.030 & 0.023 & 0.036 & 0.038 & 0.036 & na & 0.036 & $0.033 \pm 0.006$ & 20 \\
\hline & $\beta$-car & 0.033 & 0.037 & 0.035 & 0.020 & 0.044 & na & 0.051 & $0.037 \pm 0.011$ & 55 \\
\hline
\end{tabular}


Table 4 (continued)

\begin{tabular}{|c|c|c|c|c|c|c|c|c|c|c|}
\hline \multirow[t]{2}{*}{ Species } & \multirow{2}{*}{ Pigment:chl a } & \multicolumn{7}{|c|}{ - Irradiance $\left(\mu \mathrm{mol}\right.$ photons $\left.\mathrm{m}^{-2} \mathrm{~s}^{-1}\right)$} & \multirow[t]{2}{*}{ Mean \pm SD } & \multirow[t]{2}{*}{ Var } \\
\hline & & 10 & 20 & 40 & 80 & 175 & 350 & 700 & & \\
\hline \multirow{16}{*}{ Pycnococcus sp. } & Dihy & 0.032 & 0.032 & 0.032 & 0.027 & 0.027 & na & 0.037 & $0.031 \pm 0.004$ & 16 \\
\hline & Lut & nd & nd & 0.001 & nd & 0.004 & na & 0.007 & $0.004 \pm 0.003$ & \\
\hline & Neo & 0.035 & 0.041 & 0.038 & 0.040 & 0.039 & na & 0.048 & $0.040 \pm 0.004$ & 37 \\
\hline & Prasino & 0.129 & 0.128 & 0.122 & 0.145 & 0.155 & na & 0.157 & $0.139 \pm 0.015$ & 22 \\
\hline & Uri & 0.041 & 0.038 & 0.038 & 0.044 & 0.037 & na & 0.037 & $0.039 \pm 0.003$ & -10 \\
\hline & $\mathrm{V}$ & 0.024 & 0.027 & 0.032 & 0.063 & 0.076 & na & 0.062 & $0.047 \pm 0.022$ & 158 \\
\hline & $\mathrm{Z}$ & 0.008 & 0.009 & 0.011 & 0.014 & 0.026 & na & 0.047 & $0.019 \pm 0.015$ & 488 \\
\hline & Chl $b$ & 0.958 & 0.935 & 0.880 & 0.836 & 0.766 & 0.665 & 0.598 & $0.805 \pm 0.136$ & -38 \\
\hline & MgDVP & 0.046 & 0.045 & 0.051 & 0.043 & 0.037 & 0.030 & 0.028 & $0.040 \pm 0.009$ & -39 \\
\hline & $\beta$-car & 0.026 & 0.017 & 0.028 & 0.030 & 0.033 & 0.036 & 0.057 & $0.032 \pm 0.012$ & 119 \\
\hline & Dihy & 0.021 & 0.017 & 0.017 & 0.015 & 0.015 & 0.016 & 0.016 & $0.017 \pm 0.002$ & -24 \\
\hline & Lut & nd & 0.002 & nd & 0.004 & 0.037 & 0.075 & 0.112 & $0.046 \pm 0.047$ & \\
\hline & $\mathrm{Neo}$ & 0.081 & 0.068 & 0.058 & 0.053 & 0.048 & 0.042 & 0.046 & $0.057 \pm 0.014$ & -43 \\
\hline & Prasino & 0.336 & 0.327 & 0.308 & 0.310 & 0.280 & 0.267 & 0.277 & $0.301 \pm 0.026$ & -18 \\
\hline & V & 0.020 & 0.024 & 0.024 & 0.029 & 0.028 & 0.027 & 0.012 & $0.023 \pm 0.006$ & -40 \\
\hline & $\mathrm{Z}$ & 0.013 & 0.014 & 0.013 & 0.027 & 0.032 & 0.056 & 0.104 & $0.037 \pm 0.033$ & 700 \\
\hline \multirow[t]{5}{*}{ R. baltica } & $\mathrm{Chl} C_{2}$ & 0.089 & 0.081 & 0.075 & 0.080 & 0.084 & 0.068 & 0.067 & $0.078 \pm 0.008$ & -25 \\
\hline & Allo & 0.180 & 0.179 & 0.191 & 0.232 & 0.338 & 0.389 & 0.530 & $0.291 \pm 0.134$ & 194 \\
\hline & $\alpha$-car & 0.044 & 0.042 & 0.044 & 0.048 & 0.051 & 0.054 & 0.053 & $0.048 \pm 0.005$ & 20 \\
\hline & Croco & 0.037 & 0.038 & 0.038 & 0.038 & 0.034 & 0.033 & 0.030 & $0.035 \pm 0.003$ & -19 \\
\hline & Monado & 0.031 & 0.026 & 0.021 & 0.016 & 0.019 & 0.016 & 0.015 & $0.021 \pm 0.006$ & -52 \\
\hline \multirow[t]{8}{*}{ P. parvum } & $\mathrm{Chl} C_{1}$ & 0.095 & 0.088 & 0.073 & 0.061 & 0.047 & 0.036 & 0.028 & $0.061 \pm 0.026$ & -71 \\
\hline & $\mathrm{Chl} C_{2}$ & 0.029 & 0.028 & 0.019 & 0.016 & 0.013 & 0.009 & 0.012 & $0.018 \pm 0.008$ & -59 \\
\hline & $\mathrm{Chl} C_{3}$ & 0.075 & 0.075 & 0.067 & 0.055 & 0.044 & 0.039 & 0.034 & $0.056 \pm 0.017$ & -55 \\
\hline & $\alpha$-car & 0.008 & 0.011 & 0.011 & 0.010 & 0.006 & nd & nd & $0.009 \pm 0.002$ & \\
\hline & $\beta$-car & 0.015 & 0.013 & 0.017 & 0.021 & 0.022 & 0.036 & 0.045 & $0.024 \pm 0.012$ & 200 \\
\hline & $\mathrm{DD}$ & 0.047 & 0.059 & 0.083 & 0.144 & 0.261 & 0.443 & 0.481 & $0.217 \pm 0.183$ & 923 \\
\hline & $\mathrm{DT}$ & nd & 0.005 & 0.010 & 0.016 & 0.023 & 0.048 & na & $0.017 \pm 0.017$ & \\
\hline & Fuco & 0.499 & 0.523 & 0.522 & 0.494 & 0.412 & 0.390 & 0.332 & $0.453 \pm 0.075$ & -33 \\
\hline \multirow[t]{6}{*}{ P. pseudoroscoffensis } & is $\mathrm{Chl} c_{1}$ & 0.061 & 0.060 & 0.065 & 0.061 & 0.054 & 0.043 & 0.034 & $0.054 \pm 0.011$ & -44 \\
\hline & $\mathrm{Chl} c_{2}$ & 0.029 & 0.026 & 0.032 & 0.024 & 0.021 & 0.016 & 0.012 & $0.023 \pm 0.007$ & -59 \\
\hline & $\beta$-car & 0.028 & 0.029 & 0.030 & 0.031 & 0.034 & 0.040 & 0.044 & $0.034 \pm 0.006$ & 57 \\
\hline & DD & 0.071 & 0.067 & 0.069 & 0.105 & 0.168 & 0.259 & 0.291 & $0.147 \pm 0.098$ & 310 \\
\hline & DT & nd & nd & nd & nd & 0.014 & 0.043 & 0.049 & $0.035 \pm 0.019$ & \\
\hline & Fuco & 0.333 & 0.292 & 0.286 & 0.288 & 0.274 & 0.256 & 0.214 & $0.278 \pm 0.036$ & -36 \\
\hline \multirow[t]{6}{*}{ P. minimum } & $\mathrm{Chl} C_{2}$ & $\mathrm{ng}$ & $\mathrm{ng}$ & 0.231 & 0.211 & 0.206 & 0.189 & 0.199 & $0.207 \pm 0.016$ & -14 \\
\hline & $\beta$-car & $\mathrm{ng}$ & $\mathrm{ng}$ & 0.021 & 0.020 & 0.022 & 0.027 & 0.030 & $0.024 \pm 0.004$ & 43 \\
\hline & DD & $\mathrm{ng}$ & $\mathrm{ng}$ & 0.163 & 0.264 & 0.352 & 0.435 & 0.425 & $0.328 \pm 0.115$ & 161 \\
\hline & DT & $\mathrm{ng}$ & $\mathrm{ng}$ & nd & nd & 0.037 & 0.052 & 0.055 & $0.048 \pm 0.010$ & \\
\hline & Dino & $\mathrm{ng}$ & $\mathrm{ng}$ & 0.032 & 0.030 & 0.025 & 0.027 & 0.026 & $0.028 \pm 0.003$ & -19 \\
\hline & Peri & $\mathrm{ng}$ & $\mathrm{ng}$ & 0.398 & 0.392 & 0.413 & 0.392 & 0.433 & $0.406 \pm 0.018$ & 9 \\
\hline \multirow[t]{6}{*}{ S. costatum } & $\mathrm{Chl} c_{1}$ & 0.034 & 0.037 & 0.051 & 0.042 & 0.047 & 0.040 & 0.040 & $0.042 \pm 0.006$ & 18 \\
\hline & $\mathrm{Chl} C_{2}$ & 0.093 & 0.074 & 0.057 & 0.050 & 0.049 & 0.041 & 0.034 & $0.057 \pm 0.020$ & -63 \\
\hline & $\beta$-car & 0.024 & 0.025 & 0.023 & 0.027 & 0.027 & 0.030 & 0.042 & $0.028 \pm 0.006$ & 75 \\
\hline & $\mathrm{DD}$ & 0.044 & 0.049 & 0.065 & 0.111 & 0.183 & 0.323 & 0.401 & $0.168 \pm 0.143$ & 811 \\
\hline & DT & nd & nd & nd & nd & nd & nd & 0.045 & 0.045 & \\
\hline & Fuco & 0.359 & 0.401 & 0.42 & 0.433 & 0.392 & 0.372 & 0.311 & $0.384 \pm 0.041$ & -13 \\
\hline \multirow[t]{8}{*}{ F. parvula } & $\mathrm{Chl} C_{2}$ & 0.134 & 0.149 & 0.156 & 0.164 & 0.168 & 0.128 & 0.121 & $0.146 \pm 0.018$ & -10 \\
\hline & $\mathrm{Chl} c_{3}$ & 0.075 & 0.103 & 0.090 & 0.073 & 0.057 & 0.037 & 0.047 & $0.069 \pm 0.023$ & -37 \\
\hline & But-fuco & 0.202 & 0.190 & 0.195 & 0.221 & 0.219 & 0.189 & 0.278 & $0.213 \pm 0.031$ & 38 \\
\hline & $\beta$-car & 0.030 & 0.023 & 0.027 & 0.023 & 0.045 & 0.036 & 0.047 & $0.033 \pm 0.010$ & 57 \\
\hline & DD & 0.044 & 0.056 & 0.063 & 0.062 & 0.092 & 0.193 & 0.221 & $0.104 \pm 0.072$ & 402 \\
\hline & DT & nd & nd & nd & nd & nd & 0.027 & 0.079 & $0.053 \pm 0.037$ & \\
\hline & Fuco & 0.375 & 0.382 & 0.366 & 0.360 & 0.387 & 0.353 & 0.261 & $0.355 \pm 0.043$ & -30 \\
\hline & $\mathrm{Z}$ & nd & nd & nd & nd & 0.005 & 0.013 & 0.106 & $0.041 \pm 0.056$ & \\
\hline
\end{tabular}




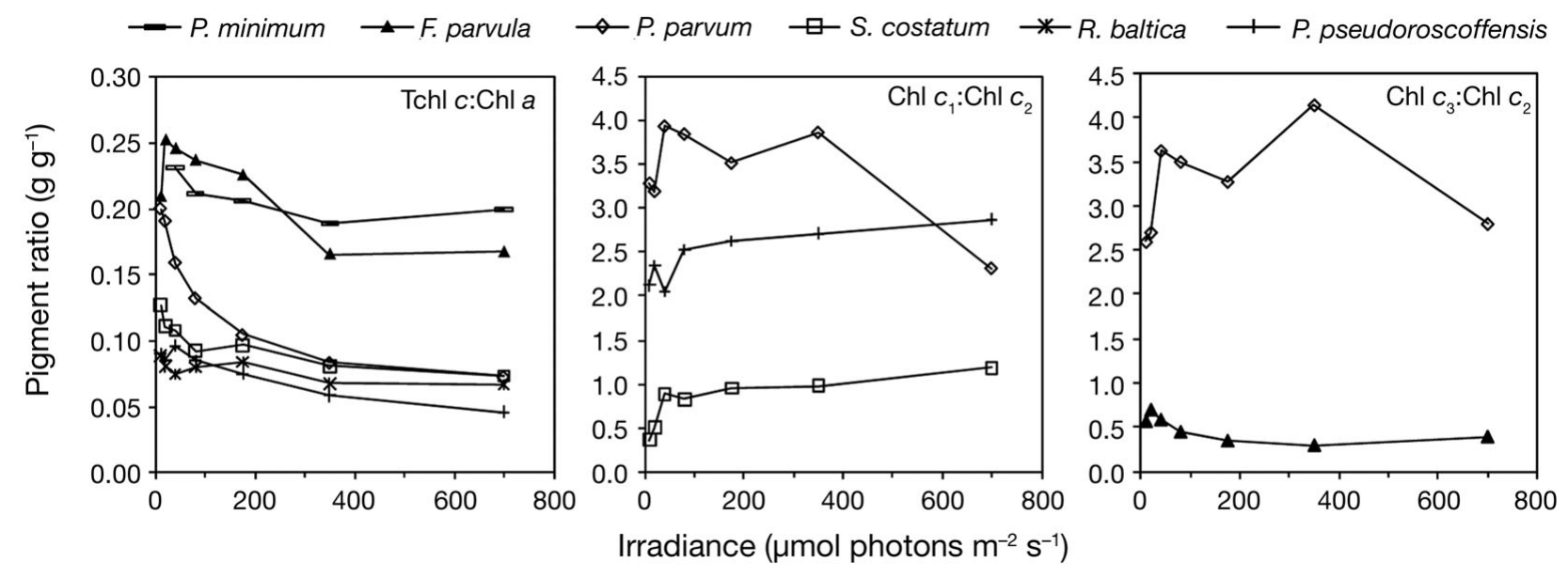

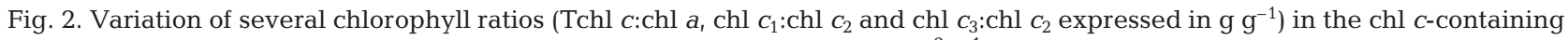
species grown under different irradiances $\left(10\right.$ to $700 \mu \mathrm{mol}$ photons $\left.\mathrm{m}^{-2} \mathrm{~s}^{-1}\right)$. Full species names are given in Table 1

Prasino:chl $a$ and Neo:chl a ratios both increased with irradiance in $O$. tauri ( +22 and $+37 \%$, respectively, $\mathrm{p}<$ 0.05) while they decreased in Pycnococcus sp. (-18\% with $\mathrm{p}<0.01$ and $-43 \%$ with $\mathrm{p}<0.001$, respectively) or remained stable in $M$. pusilla ( $p>0.46$ and 0.05, respectively). Finally, the minor pigments Dihy and Uri did not vary significantly with irradiance regardless of the studied species (Table 4). In comparison, the chlorophyte Dunaliella tertiolecta also presented an increase of the Neo:chl a ratio when cultivated at higher irradiance $(+57 \%, \mathrm{p}<0.05)$.

The most pronounced effect of irradiance on xanthophylls was seen for the photoprotective pigments DD, DT, Allo, Lut and Z, with a dramatic increase (up to 10-fold for DD in Prymnesium parvum) of the pigment:chl a ratios regardless of the species exposed to high light conditions (Table 4). In Synechococcus sp., the cellular chl $a$ and $\mathrm{Z}$ content decreased from 10 to $700 \mu \mathrm{mol}$ photons $\mathrm{m}^{-2} \mathrm{~s}^{-1}$ by a factor of 4 and 2, respectively (data not shown). Therefore, the $\mathrm{Z}$ :chl a ratio increased by a factor of 2 (0.781 to 1.680$)$. In general, the total pool of pigments involved in the xanthophyll cycle (DD-DT or V-A-Z) increased with irradiance (Fig. 3 ). Values of the chl a-normalised ratio (cycle: chl a) were comparable for species grown at low irradiance $\left(0.045 \pm 0.015\right.$ at $10 \mu \mathrm{mol}$ photons $\left.\mathrm{m}^{-2} \mathrm{~s}^{-1}\right)$. At $700 \mu \mathrm{mol}$ photons $\mathrm{m}^{-2} \mathrm{~s}^{-1}$, it reached values between 0.481 (Prorocentrum minimum) and 0.110 (Ostreococcus tauri) and was higher in chl $b$-containing $(0.391 \pm 0.086)$ than in chl $c$-containing $(0.159 \pm 0.054)$ species. The contribution of this pool to the total amount of pigments (cycle:Tpig) demonstrated an overall similar pattern of variations (Fig. 3). The evolution of the DR showed that the behaviour of the xanthophyll cycle largely differed among species (Fig. 3). In species containing chl $C_{\text {, DT }}$ was generally detected in cultures grown at an irradi- ance $\geq 175 \mu \mathrm{mol}$ photons $\mathrm{m}^{-2} \mathrm{~s}^{-1}$, and DR values rarely exceeded 0.20 (0.26 in Florenciella parvula at $700 \mu \mathrm{mol}$ photons $\mathrm{m}^{-2} \mathrm{~s}^{-1}$ ). In comparison, the xanthophyll cycle in chl $b$-containing species (conversion of $\mathrm{V}$ into $\mathrm{Z}$ via A, the latter pigment being detected only in Dunaliella tertiolecta) was relatively more active, except for Micromonas pusilla. For example, O. tauri and Pycnococcus sp. synthesised significant amounts of Z (DR > 0.25) even in low light conditions. Moreover, Pycnococcus sp. and D. tertiolecta presented the highest value of DR (around 0.90) at $700 \mu \mathrm{mol}$ photons $\mathrm{m}^{-2} \mathrm{~s}^{-1}$.

Finally, the ratio of $\beta$-car to chl a showed contrasting patterns, as it decreased with increasing irradiance in Synechococcus sp. $(-39 \%, \mathrm{p}<0.01)$ whereas it increased or remained stable elsewhere (Ostreococcus tauri and Dunaliella tertiolecta, Table 4). In the meantime, $\alpha$-car decreased in D. tertiolecta $(\mathrm{p}<0.05)$ and Prymnesium parvum $(\mathrm{p}<0.01)$ and increased in Rhodomonas baltica $(\mathrm{p}<0.01)$.

\section{Determination of relationships between irradiance and chl a-normalised pigment ratios}

The variation of each chl a-normalised pigment ratio with culture irradiance was analysed by means of linear regressions, which represented 79 relationships to be determined. According to the determination coefficients $\left(\mathrm{R}^{2}\right)$ and the $\mathrm{p}$ value associated with the estimated slope $(b)$ from the different models tested ('linear', 'logistic', 'exponential' and 'power'), it appeared that these simple 2-parameter models globally fitted well to the data (Supplement 1 at www.int-res.com/ articles/suppl/m425p063_supp.pdf). Of these relationships, 62 were statistically significant using at least one of these models, and $82 \%$ of these relationships were 


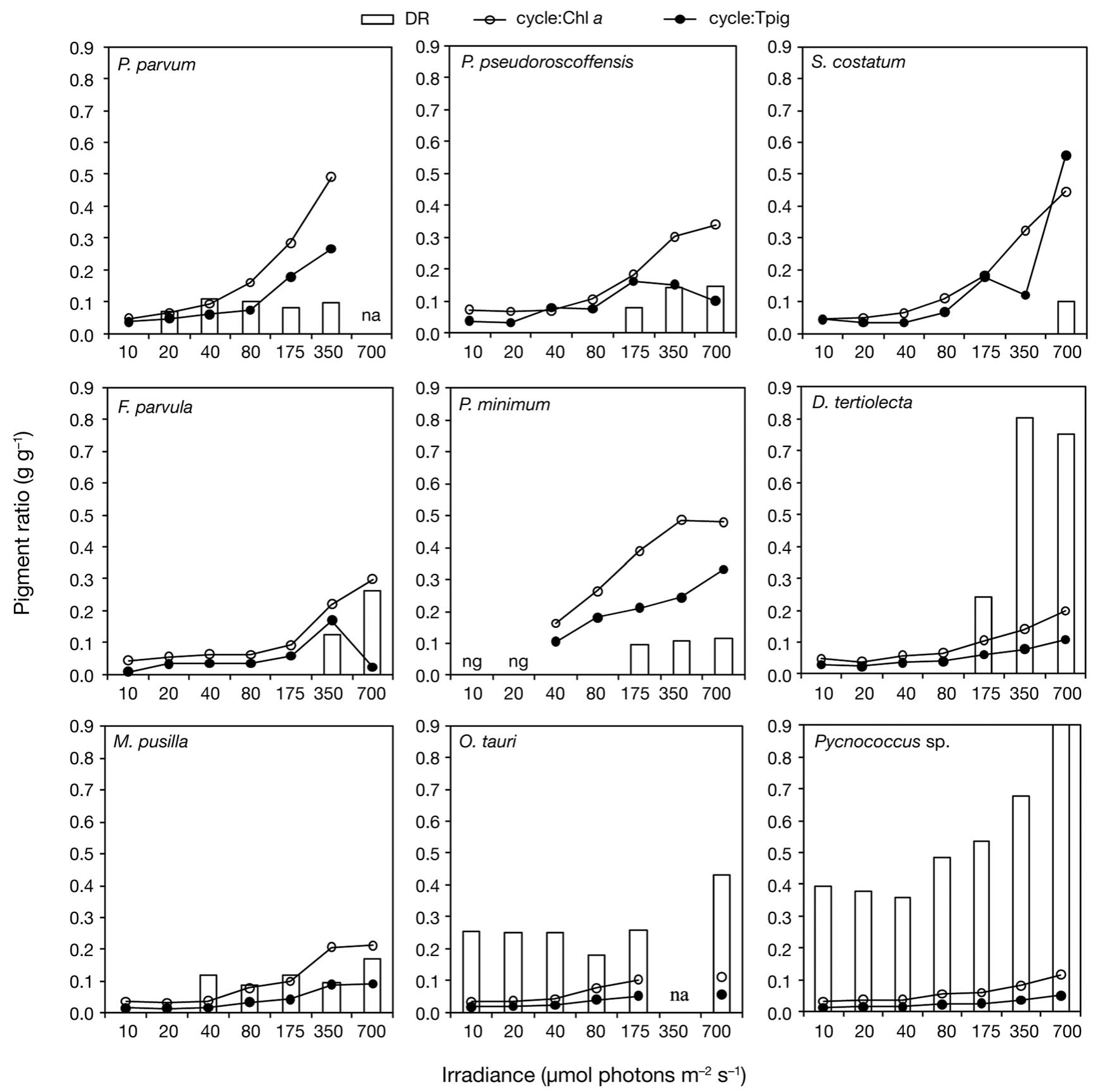

Fig. 3. Variation of the DD-DT and V-A-Z pools normalised to chl a (cycle:chl a in $\mathrm{g} \mathrm{g}^{-1}$ : open circles) or to the total amount of pigments (cycle:Tpig in $\mathrm{g} \mathrm{g}^{-1}$ : black circles) and the de-epoxydation ratio (DR, open bar) in species demonstrating a xanthophyll cycle grown under different irradiances $\left(10\right.$ to $700 \mu \mathrm{mol}$ photons $\left.\mathrm{m}^{-2} \mathrm{~s}^{-1}\right)$. Note that $F$. parvula also accumulated a significant amount of $\mathrm{Z}$ under high light exposure but no trace of V or Z was detected. ng: no growth; na: data not available. Full species names are given in Table 1 and full pigment names in Table 2

well defined using the 'linear' model (Eq. 3), with highly significant (at least $\mathrm{p}<0.01$ ) calculated slopes (b) in $60 \%$ of the cases (i.e. $37 / 62$, Supplement 1). In comparison, the results obtained by means of the TableCurve software indicated that the use of more complex (i.e. non-linear 2-parameter model) but biologically relevant models (e.g. Weibull or log-logistic models) did not significantly improve the accuracy of the estimations. Furthermore, it appeared that other linearisable but 3-parameter models $\left(Y=a+b \mathrm{e}^{-X / c}\right.$ or $Y=a+b X^{c}$ ) fitted substantially better to the data for chl $c_{3}$, But-fuco and Z in Florenciella parvula, chl $c_{2}$, Dino and Peri in Prorocentrum minimum, chl $b$, MgDVP and Dihy in Pycnococcus sp., chl $b$ and Uri in 
Micromonas pusilla, $\beta$-car in Synechococcus sp. and chl $c_{2}$ in Prymnesium parvum (Supplement 1).

Considering the pigments shared by several species, the results showed that they could be divided into 3 groups according to their responses to irradiance via changes in the pigment:chl a ratio. The first group included those similarly correlated with culture irradiance regardless of the species studied: $\operatorname{chl} b$, Tchl $c_{\text {, }}$ chl $c_{3}$, Z, Lut, DD, DT and Fuco. Pigments such as $\alpha$ and $\beta$-car, chl $c_{1}$ and $c_{2}, \mathrm{MgDVP}, \mathrm{Neo}$, Prasino and V were placed in a second group explained by their contrasting variation patterns among species. Finally, Uri and Dihy fell into a third group, as their ratios to chl a never co-varied with irradiance, regardless of the species studied (Supplement 1). For some pigments of the first group, data from individual species were standardised and pooled (Fig. 4). Between-factors ANOVAs were used to detect interspecific differences of each pigment ratio variation with irradiance. The interaction was highly insignificant regardless of the
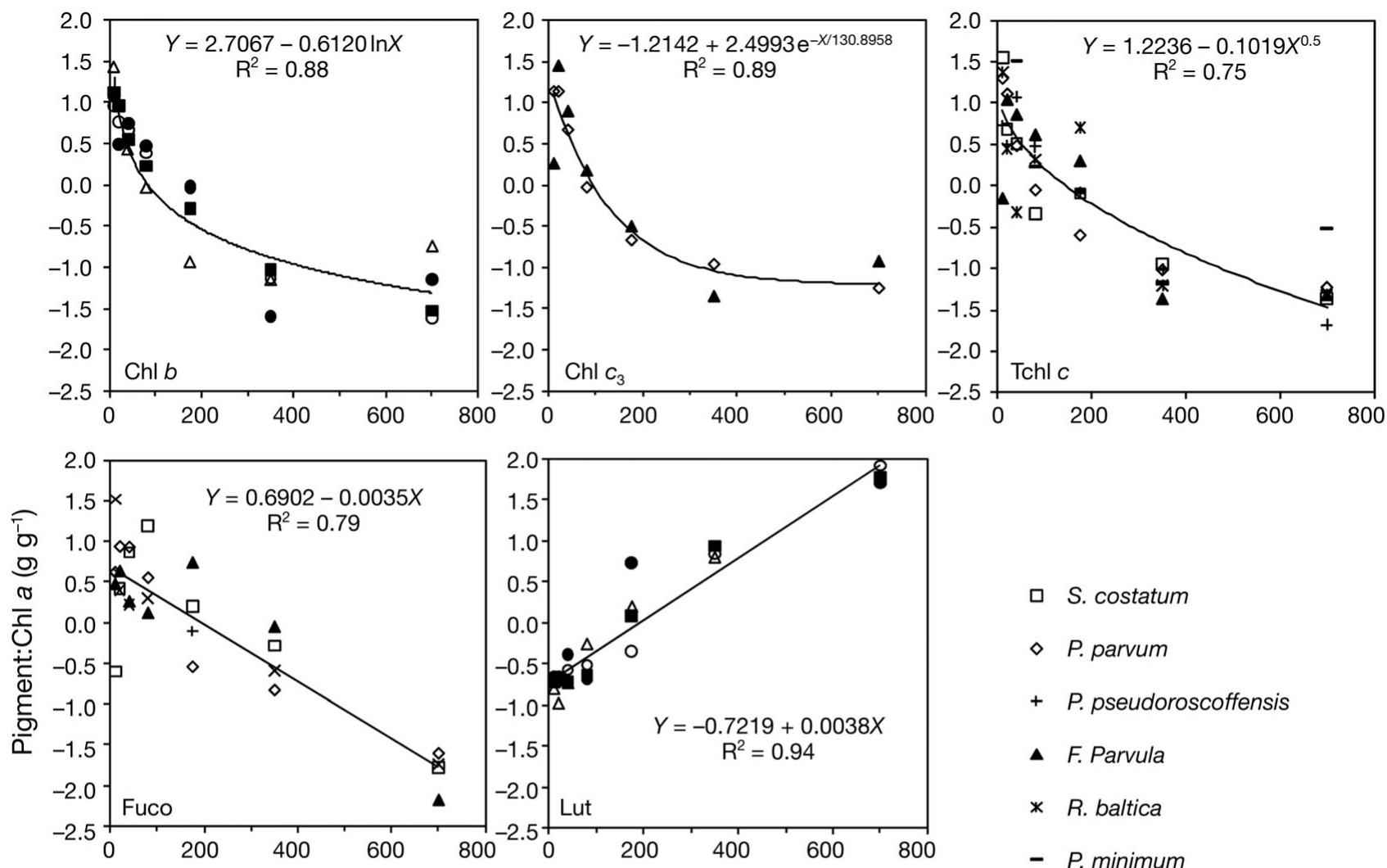

․ S. costatum

$\diamond \quad$ P. parvum

$+\quad P$. pseudoroscoffensis

- F. Parvula

* R. baltica

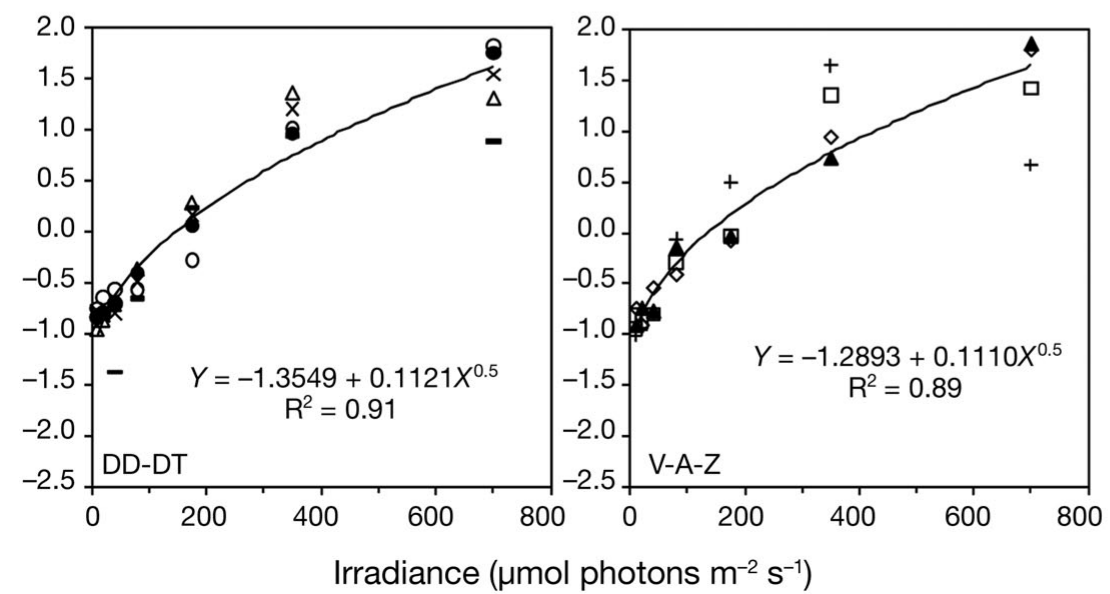

- P. minimum

○ M. pusilla

$\Delta$ D. tertiolecta

- Pycnococcus sp.

- Synechococcus sp.

- O. tauri

Fig. 4. Variation of selected pigments ( $\mathrm{chl} b, \mathrm{chl} c_{3}$, Fuco, Lut and the Tchl $c_{1}$ DD-DT and V-A-Z pools; full pigment names are given in Table 2) normalised to chl $a$ in species grown under different irradiances (10 to $700 \mu \mathrm{mol}$ photons $\mathrm{m}^{-2} \mathrm{~s}^{-1}$ ). For each pigment, data from individual species were first standardised and then pooled. The solid lines indicate the best fitted equations. Full species names are given in Table 1 
Table 5. Summary of regression analysis between selected pigments (chl $b$, chl $c_{3}$, Fuco, Lut and the Tchl $c$, DD-DT and V-A-Z pools; full pigment names are given in Table 2) normalised to chl $a$ and the growth irradiance using the 'linear' model $(Y=a X+b)$. For each ratio, data from individual species were first standardised and then pooled. The estimations of the intercept $(a)$ and the relative slope $(b)$, the determination coefficient $\left(\mathrm{R}^{2}\right)$ and the number of samples (n) are given

\begin{tabular}{|lcrrr|}
\hline \multirow{2}{*}{ Pigment:chl $a$} & \multicolumn{4}{c}{ Linear regression } \\
\cline { 2 - 5 } & $\mathrm{R}^{2}$ & $a$ & \multicolumn{1}{c|}{$b$} & $\mathrm{n}$ \\
\hline Chl $b$ & 0.73 & 0.6665 & -0.0034 & 28 \\
Chl $c_{3}$ & 0.64 & 0.6215 & -0.0032 & 14 \\
Fuco & 0.79 & 0.6901 & -0.0035 & 28 \\
Lut & 0.94 & -0.7218 & 0.0038 & 28 \\
Tchl $c$ & 0.67 & 0.6600 & -0.0032 & 40 \\
DD-DT & 0.85 & -0.7466 & 0.0036 & 33 \\
V-A-Z & 0.81 & -0.7409 & 0.0038 & 28 \\
\hline
\end{tabular}

ratio studied (species $\times$ irradiance: $0.80 \leq p \leq 0.97$ ), thereby allowing us to determine generalised relationships. Hence, the 'linear' model (Eq. 3) was more adapted than the other simple equations (Eqs. 7 to 9 ) regardless of the pigment studied ( $p<0.001$, Table 5). However, other non-linear models better fitted the data for $\operatorname{chl} b(Y=a+b \ln X)$, $\operatorname{chl} c_{3}\left(Y=a+b \mathrm{e}^{-X / c}\right)$ or for the pools Tchl $c_{\text {, DD-DT }}$ and V-A-Z $\left(Y=a+b X^{0.5}\right.$; Fig. 4).

\section{DISCUSSION}

\section{Comparison with literature data of pigment composition and pigment ratios}

Pigment signatures of the 11 phytoplankton species are in good agreement with profiles that have been established for the same species or at least species of the same chemotaxonomic group (Jeffrey \& Vesk 1997 , Eikrem et al. 2004, Zapata 2005). Nevertheless, some differences between our results and those provided in the literature can be pointed out regarding minor pigments. For instance, several authors focusing on Prymnesium parvum described low amounts of chl $C_{2}$-monogalactosyl-diacylglycerol that were not observed in the present study (Zapata et al. 2001, 2004, Rodriguez et al. 2006, Laza-Martinez et al. 2007). Moreover, we detected MgDVP only in Prasinophyceae, whereas it is usually found as a minor compound in almost all species recently analysed (Zapata 2005). Considering that the same $\mathrm{C}_{8}$ reversed-phase separation method was applied (Zapata et al. 2000), these differences could be partly ascribed to a lower detection limit of the HPLC diode arrays.

Despite the wide light gradient used in this work (10 to $700 \mu \mathrm{mol}$ photons $\mathrm{m}^{-2} \mathrm{~s}^{-1}$ ), the mean values of the pigment:chl a ratios generally fell within the ranges previously reported for species of the same taxa (Mackey et al. 1996, Llewellyn \& Gibb 2000, Schlüter et al. 2000, Henriksen et al. 2002, Rodriguez et al. 2006, Seoane et al. 2009). However, some differences may arise when comparing our results to studies which focused on the same species, probably because different isolates of the same species may have experienced contrasted environmental conditions (e.g. light history). This could also be due to methodological biases. For instance, mean values of $\mathrm{chl} b: \mathrm{chl} a(0.220 \pm 0.024)$ and Neo:chl a $(0.027 \pm 0.007)$ ratios in Dunaliella tertiolecta were significantly lower than those presented for the same species ( 0.444 to 0.488 and 0.088 to 0.161 , respectively) cultivated in a similar light gradient (Fujiki \& Taguchi 2002). In the same way, the mean value of Peri:chl a ratio $(0.406 \pm 0.018)$ was lower than in 2 other strains of Prorocentrum minimum (0.84 to 1.3) grown at 35 and $500 \mu \mathrm{mol}$ photons $\mathrm{m}^{-2} \mathrm{~s}^{-1}$ (Johnsen \& Sakshaug 1993). Nevertheless, it was closer to that (0.3) reported by Rodriguez et al. (2006). Considering Prymnesium parvum and Pleurochrysis pseudoroscoffensis, it appears that $c_{1}$ and $c_{3}$ are the dominant chl $c$-type pigments in these haptophytes ( $\operatorname{chl~} c_{1}: \operatorname{chl} a>$ $\operatorname{chl} c_{3}: \operatorname{chl} a>\operatorname{chl} C_{2}: \operatorname{chl} a$ ), confirming previous studies but with different relative proportions (i.e. chl $C_{1}$ :chl $C_{2}$ and chl $C_{3}$ :chl $C_{2}$ ratios; Rodriguez et al. 2006, LazaMartinez et al. 2007, Seoane et al. 2009).

\section{Effect of light on pigment ratios}

In this study, the PAR dependence of each pigment was determined in terms of amplitude and shape of the pigment:chl a ratio versus irradiance curve. The amplitude of variation observed between low and high light conditions (10 and $700 \mu \mathrm{mol}$ photons $\mathrm{m}^{-2} \mathrm{~s}^{-1}$ ) depended on the putative function of the pigment studied. All species increased their light-harvesting capability by increases in cellular chl a content. A light-harvesting function could also be attributed to pigments for which the corresponding pigment:chl a ratios decreased or presented a limited variability (less than $40 \%$ on average). This was the case for the abundant Fuco, Peri and chl $b$, as previously described in phytoplankton by several authors (Schlüter et al. 2000, Henriksen et al. 2002, Rodriguez et al. 2006, Seoane et al. 2009). Considering the different chlorophylls $c_{r}$ the variation patterns observed were species specific but globally suggested a potential role in light harvesting for these pigments (Johnsen \& Sakshaug 1993, Schlüter et al. 2000, Rodriguez et al. 2006, Seoane et al. 2009). This function was also evident for the minor pigments Uri, Dihy (detected in Micromonas pusilla and Ostreococcus tauri), Dino, Monado and Croco (Rhodomonas baltica) 
for which data available in the literature are scarce (but see Böhme et al. 2002, Six et al. 2008, 2009). The fact that Neo and Prasino presented contrasting patterns among species agrees with several comparable multispecies studies (Schlüter et al. 2000, Rodriguez et al. 2006). These results did not allow us to confirm several authors focusing on the Prasinophytes Mantoniella squamata and $O$. tauri who showed that these pigments are involved in light harvesting (Böhme et al. 2002, Six et al. 2008). In addition, the trends demonstrated by the $\operatorname{chl} c_{1}: \mathrm{chl} c_{2}$ and $\mathrm{chl} c_{3}: \mathrm{chl} c_{2}$ ratios do not support the hypothesis that light playing a role in the balanced regulation of the chlorophylls $c$ synthesis could be considered as a general rule (Zapata et al. 2006). For instance, the present findings do not confirm a previous study focusing on haptophytes which showed that chl $C_{2}$ was the dominant form to the detriment of $\mathrm{chl} C_{3}$ in higher light conditions (Seoane et al. 2009).

As expected, pigments related to the xanthophyll cycle (DD-DT or V-A-Z) exhibited clear light-induced patterns. The accumulation of these pigments illustrates a reorganisation of the photosynthetic apparatus in order to protect cells from oxidative stress inherent to higher light conditions (MacIntyre et al. 2002). In the field, an effective operation of the xanthophyll cycle may help the cells to respond within 1 min to a sudden increase of light by dissipating excess absorbed energy as thermal radiation (Falkowski \& Raven 1997). The present work revealed a great inter-specific variability of both the total pool of pigments involved in the xanthophyll cycle and the de-epoxidation state (DR). This reflects the high diversity in photoprotective strategies existing in phytoplankton which is generally interpreted as an important functional trait for specific adaptation of microalgae to the various pelagic ecological niches (Brunet et al. in press). However, the DR estimated here offers only a partial view of the potential efficiency of this mechanism which must be investigated in terms of kinetic and light threshold that activates $\mathrm{DT}$ or $\mathrm{Z}$ synthesis in the context of short-term variation of the light environment (e.g. Lavaud et al. 2004, Dimier et al. 2009, Six et al. 2009). Florenciella parvula synthesised a significant amount of $\mathrm{Z}$ from $175 \mu \mathrm{mol}$ photons $\mathrm{m}^{-2} \mathrm{~s}^{-1}$ in addition to the DD-DT cycle, confirming that 2 xanthophyll cycles can cooccur, although the real physiological significance of this phenomenon is still unclear (Lohr \& Wilhelm 1999).

The present work highlights the potential contribution of other xanthophylls in long-term photoprotective mechanisms. In Rhodomonas baltica, a species with no xanthophyll cycle, a photoprotective function can be assigned to Allo with regard to the nearly 3-fold increase of its ratio to chl $a$ between 10 and $700 \mu \mathrm{mol}$ photons $\mathrm{m}^{-2} \mathrm{~s}^{-1}$. However, this mechanism does not seem to be a general rule in cryptophytes (Schlüter et al. 2000, Henriksen et al. 2002). This is also illustrated by the positive correlation observed in the 4 chlorophytes (but to a lower extent in Ostreococcus tauri) between the Lut:chl a ratio and the irradiance (Schlüter et al. 2000, Henriksen et al. 2002, Rodriguez et al. 2006). In contrast, the ca. 2-fold increase of the Z:chl a ratio observed in Synechococcus sp. cannot be explained by an active accumulation of the carotenoid under high light exposure. Indeed, the cellular contents of chl a, $\beta$-car and $\mathrm{Z}$ both decreased with increasing irradiance. A comparable passive photoprotective trend of Z was reported in other marine Synechococcus strains but with a $\mathrm{Z}$ quota remaining constant regardless of the growth irradiance (Kana et al. 1988, Moore et al. 1995, Lutz et al. 2001, Six et al. 2004). As illustrated by the still high $\mathrm{Z}: \mathrm{chl}$ a ratio at $10 \mu \mathrm{mol}$ photons $\mathrm{m}^{-2} \mathrm{~s}^{-1}(0.78)$, it was assumed here that some $\mathrm{Z}$ molecules were localised within the thylakoid membranes where they probably played a role in light harvesting (Masamoto et al. 1999). A sharp reduction in thylakoid surfaces at high light could have led to a decrease of this pigment pool (Kana \& Glibert 1987). In the meantime, an accumulation of $\mathrm{Z}$ in the cytoplasmic membranes via a direct synthesis from $\beta$-car (see the opposite trend of the $\beta$-car:chl a) would have helped the cells to limit photodamage (Masamoto et al. 1999), thereby resulting in a slower decrease of its total cellular content in comparison to $\beta$-car and chl $a$. In Florenciella parvula, the opposite trends observed for Fuco and But-fuco support the hypothesis initially proposed in the haptophyte Phaeocystis sp. that the hydroxylation of the former pigment into the latter may help the cells to limit oversupplying energy in high light conditions (van Leeuwe \& Stefels 1998). However, this mechanism requires further investigation as it is still under debate (Stolte et al. 2000) and is not clearly supported by the few quantitative data available on Butfuco (Seoane et al. 2009).

Considering the shape of the curves, most of the relationships $(82 \%)$ between the pigment:chl $a$ ratios and irradiance were rather well described $(p<0.01)$ using at least one of our simple linear models (Eqs. 3 to $6)$. For some of the poorly explained $(0.05<\mathrm{p}<0.01)$ but evident trends (e.g. chl $C_{2}$ in Skeletonema costatum and Rhodomonas baltica, Fuco in S. costatum, V in Dunaliella tertiolecta), it is assumed that additional replicates would improve the accuracy of our estimations. When pooling the standardised data, it appears that a unique model could be used to explain the lightinduced variation of several pigments (Lut, Fuco, $\mathrm{Chl} b, \mathrm{Chl} c_{3}$ ) or groups of pigments (DD-DT, V-A-Z, Tchl $c$ ) regardless the species studied. This confirms the results of a previous study comparing 2 strains (cal- 
cifying or noncalcifying) of the haptophyte Emiliana huxleyi with clearly different physiological properties (Leonardos \& Harris 2006). Hence, they exhibited the same trends and magnitude of change for the following pigments (normalised to chl a): Fuco, 19' hexanoyloxyfucoxanthin (Weibull model) and the pools of chlorophylls $c$ and DD-DT ('linear' model).

\section{Conclusion and potential perspectives in chemotaxonomic studies}

Quantitative relationships between pigment ratios and irradiance were determined on a large light intensity range (10 to $700 \mu \mathrm{mol}$ photons $\mathrm{m}^{-2} \mathrm{~s}^{-1}$ ) for marine phytoplankton species belonging to various taxa. They could serve in the future development of models dedicated to the estimation of phytoplankton community structure in natural samples. Altogether, our results provide a comprehensive assessment of intra-class and intra-species variability of the pigment content in microalgae which is modulated by environmental factors (light in this study) within boundaries that are probably genetically predefined. Up to now, the proposed statistical methods failed to take into account this variability, in particular the CHEMTAX program, which is extensively used to determine community structure in waters from pigment data. Hence, the designers of the CHEMTAX program recommend that users focus on pigments (normalised to chl a) susceptible to limited variation $(<25 \%)$ and eventually group the natural samples in homogeneous subsets when investigating an area presenting evident contrasting populations and/or environmental conditions (Mackey et al. 1996). However, this a priori choice of the relevant endpoints to be considered implies that part of the information underlying the structure of the data is lost. To overcome this problem, the use of more advanced modelling techniques such as artificial neural networks should offer a relevant alternative tool. Indeed, this type of approach has already obtained successful results in community classification in diverse ecosystems (Lek \& Guégan 2000). These methods are known to perform the same task as principal component analysis but with the ability to cope with non-linear relationships. In particular, the self-organising map (SOM) algorithm, a non-supervised neural network method, was designed to extract pertinent objective information embedded in such highly dimensional (i.e. the number of pigment ratios to be considered) and heterogeneous (i.e. the complex relationships between pigments) data sets from their statistical properties only. The results are uninfluenced by a priori knowledge of samples and of environmental features (Kohonen 1995). This study is the first step of a programme aiming to test the suitability of the SOM for the determination of phytoplankton community structure using pigments. Our ongoing work consists of using these data to develop an SOM which comprises several neurons, each neuron representing a hypothetical assemblage of species characteristic of a given irradiance. Our guess is that this map will allow us to invert the pigment content of an experimental simplified assemblage of species to retrieve information concerning its community structure regardless of the light level previously encountered in the laboratory. In that case, the last step will be to apply the neural network to the more complex problem of natural phytoplankton community structure determination. This will necessitate a larger data set to be implemented taking into account all the factors that may contribute to pigment variability in the field (e.g. taxonomy, light quality, nutrient availability, hydrodynamics).

Acknowledgements. We thank K. Escoubeyrou for assistance with HPLC pigment analysis, B. Rivière for help in preparing culture media and performing flow cytometry analyses and 3 anonymous reviewers for helpful comments on the manuscript.

\section{LITERATURE CITED}

Böhme K, Wilhelm C, Goss R (2002) Light regulation of carotenoid biosynthesis in the prasinophycean alga Mantoniella squamata. Photochem Photobiol Sci 1:619-628

Brunet C, Johnsen G, Lavaud J, Roy S (2011) Selected pigment applications in oceanography: pigments and photoacclimation processes. In: Roy S, Llewellyn C, Egeland SE, Johnsen G (eds) Phytoplankton pigments: characterization, chemotaxonomy and applications in oceanography, Part IV; Chap 11. Cambridge Environmental Chemistry Series, Cambridge University Press (in press)

Campbell L, Vaulot D (1993) Photosynthetic picoplankton community structure in the Subtropical North Pacific Ocean near Hawaii (Station Aloha). Deep Sea Res I 40: 2043-2060

Crawley MJ (2007) The R book. John Wiley \& Sons Ltd, Chichester

Dimier C, Giovanni S, Ferdinando T, Brunet C (2009) Comparative ecophysiology of the xanthophyll cycle in six marine phytoplanktonic species. Protist 160:397-411

Eikrem W, Romari K, Latasa M, Le Gall FJ, Throndsen J, Vaulot D (2004) Florenciella parvula gen. and sp. nov. (Dictyochophyceae, Heterokontophyta) a small flagellate isolated from the English Channel. Phycologia 43: 658-668

Falkowski P, Raven JA (1997) Aquatic photosynthesis. Blackwell Science, Oxford

Falkowski PG, Barber RT, Smetacek V (1998) Biogeochemical controls and feedbacks on ocean primary production. Science 281:200-206

> Fenchel T (1988) Marine plankton food-chains. Annu Rev Ecol Syst 19:19-38

Field CB, Behrenfeld MJ, Randerson JT, Falkowski P (1998) Primary production of the biosphere: integrating terrestrial and oceanic components. Science 281:237-240 
Fujiki T, Taguchi S (2002) Variability in chlorophyll a specific absorption coefficient in marine phytoplankton as a function of cell size and irradiance. J Plankton Res 24:859-874

Goericke R, Montoya JP (1998) Estimating the contribution of microalgal taxa to chlorophyll $a$ in the field - variations of pigment ratios under nutrient- and light-limited growth. Mar Ecol Prog Ser 169:97-112

Guillard RR, Ryther JH (1962) Studies of marine planktonic diatoms. 1. Cyclotella nana Hustedt, and Detonula confervacea (Cleve) Gran. Can J Microbiol 8:229-239

Guillou L, Eikrem W, Chretiennot-Dinet MJ, Le Gall F and others (2004) Diversity of picoplanktonic prasinophytes assessed by direct nuclear SSU rDNA sequencing of environmental samples and novel isolates retrieved from oceanic and coastal marine ecosystems. Protist 155: 193-214

Henriksen P, Riemann B, Kaas H, Sorensen HM, Sorensen HL (2002) Effects of nutrient-limitation and irradiance on marine phytoplankton pigments. J Plankton Res 24: 835-858

Ihaka R, Gentleman R (1996) R: a language for data analysis and graphics. J Comput Graph Statist 5:299-314

Jeffrey SW (1997) Chlorophyll and carotenoid extinction coefficients. In: Jeffrey SW, Mantoura RFC, Wright SW (eds) Phytoplankton pigments in oceanography: guidelines to modern methods. UNESCO, Paris, p 595-596

Jeffrey SW, Vesk M (1997) Introduction to marine phytoplankton and their pigment signatures. In: Jeffrey SW, Mantoura RFC, Wright SW (eds) Phytoplankton pigments in oceanography: guidelines to modern methods. UNESCO, Paris, p 37-84

Jeffrey SW, Mantoura RFC, Bjørnland T (1997) Data for the identification of 47 key phytoplankton pigments. In: Jeffrey SW, Mantoura RFC, Wright SW (eds) Phytoplankton pigments in oceanography: guidelines to modern methods. UNESCO, Paris, p 447-560

> Jeffrey SW, Wright SW, Zapata M (1999) Recent advances in HPLC pigment analysis of phytoplankton. Mar Freshw Res 50:879-896

> Johnsen G, Sakshaug E (1993) Biooptical characteristics and photoadaptive responses in the toxic and bloom-forming dinoflagellates Gyrodinium aureolum, Gymnodinium galatheanum, and 2 strains of Prorocentrum minimum. J Phycol 29:627-642

Kana TM, Glibert PM (1987) Effect of irradiances up to $2000 \mu \mathrm{E} \mathrm{m} \mathrm{m}^{-2} \mathrm{~s}^{-1}$ on marine Synechococcus WH7803. 1. Growth, pigmentation, and cell composition. Deep-Sea Res 34:479-495

Kana TM, Glibert PM, Goericke R, Welschmeyer NA (1988) Zeaxanthin and beta-carotene in Synechococcus WH7803 respond differently to irradiance. Limnol Oceanogr 33: 1623-1627

Keller MD, Selvin RC, Claus W, Guillard RRL (1987) Media for the culture of oceanic ultraphytoplankton. J Phycol 23:633-638

Kohonen T (1995) Self-organizing maps. Springer Verlag, Berlin

> Larsen A (1999) Prymnesium parvum and P. patelliferum (Haptophyta) - one species. Phycologia 38:541-543

- Latasa M, Scharek R, Le Gall F, Guillou L (2004) Pigment suites and taxonomic groups in Prasinophyceae. J Phycol 40:1149-1155

> Lavaud J, Rousseau B, Etienne AL (2004) General features of photoprotection by energy dissipation in planktonic diatoms (Bacillariophyceae). J Phycol 40:130-137

> Laza-Martinez A, Seoane S, Zapata M, Orive E (2007) Phytoplankton pigment patterns in a temperate estuary: from unialgal cultures to natural assemblages. J Plankton Res 29:913-929

Lek S, Guégan JF (2000) Artificial neuronal networks, applications to ecology and evolution. Springer-Verlag, Berlin

Leonardos N, Harris GN (2006) Comparative effects of light on pigments of two strains of Emiliania huxleyi (Haptophyta). J Phycol 42:1217-1224

Lewin RA, Krienitz L, Goericke R, Takeda H, Hepperle D (2000) Picocystis salinarum gen. et sp. nov. (Chlorophyta)-a new picoplanktonic green alga. Phycologia 39: 560-565

> Liu H, Probert I, Uitz J, Claustre H and others (2009) Extreme diversity in noncalcifying haptophytes explains a major pigment paradox in open oceans. Proc Natl Acad Sci USA 106:12803-12808

- Llewellyn CA, Gibb SW (2000) Intra-class variability in the carbon, pigment and biomineral content of prymnesiophytes and diatoms. Mar Ecol Prog Ser 193:33-44

> Llewellyn C, Fishwick JR, Blackford JC (2005) Phytoplankton community assemblage in the English Channel: a comparison using chlorophyll a derived from HPLC-CHEMTAX and carbon derived from microscopy cell counts. J Plankton Res 27:103-119

> Lohr M, Wilhelm C (1999) Algae displaying the diadinoxanthin cycle also possess the violaxanthin cycle. Proc Natl Acad Sci USA 96:8784-8789

Lutz VA, Sathyendaranath S, Head EJH, Li WKW (2001) Changes in the in vivo absorption and fluorescence excitation spectra with growth irradiance in three species of phytoplankton. J Plankton Res 23:555-569

> MacIntyre HL, Kana TM, Anning T, Geider RJ (2002) Photoacclimation of photosynthesis irradiance response curves and photosynthetic pigments in microalgae and cyanobacteria. J Phycol 38:17-38

> Mackey MD, Mackey DJ, Higgins HW, Wright SW (1996) CHEMTAX - a program for estimating class abundances from chemical markers: application to HPLC measurements of phytoplankton. Mar Ecol Prog Ser 144:265-283

Mackey DJ, Blanchot J, Higgins HW, Neveux J (2002) Phytoplankton abundances and community structure in the equatorial Pacific. Deep-Sea Res 49:2561-2582

Masamoto K, Zsiros O, Gombos Z (1999) Accumulation of zeaxanthin in cytoplasmic membranes of the cyanobacterium Synechococcus sp. strain PCC7942 grown under high light condition. J Plant Physiol 155:136-138

> Moore LR, Goericke R, Chisholm SW (1995) Comparative physiology of Synechococcus and Prochlorococcusinfluence of light and temperature on growth, pigments, fluorescence and absorptive properties. Mar Ecol Prog Ser $116: 259-275$

Neveux J (1988) Extraction of chlorophylls from marine phytoplankton. Verh Int Verein Limnol 23:928-932

> Rodriguez F, Derelle E, Guillou L, Le Gall F, Vaulot D, Moreau $\mathrm{H}$ (2005) Ecotype diversity in the marine picoeukaryote Ostreococcus (Chlorophyta, Prasinophyceae). Environ Microbiol 7:853-859

Rodriguez F, Chauton M, Johnsen G, Andresen K, Olsen LM, Zapata M (2006) Photoacclimation in phytoplankton: implications for biomass estimates, pigment functionality and chemotaxonomy. Mar Biol 148:963-971

Schlüter L, Mohlenberg F, Havskum H, Larsen S (2000) The use of phytoplankton pigments for identifying and quantifying phytoplankton groups in coastal areas: testing the influence of light and nutrients on pigment/chlorophyll a ratios. Mar Ecol Prog Ser 192:49-63

> Seoane S, Zapata M, Orive E (2009) Growth rates and pigment patterns of haptophytes isolated from estuarine waters. J Sea Res 62:286-294 
Shi XL, Marie D, Jardillier L, Scanlan DJ, Vaulot D (2009) Groups without cultured representatives dominate eukaryotic picophytoplankton in the oligotrophic South East Pacific Ocean. PLoS ONE 4:e7657

Silva PC, Throndsen J, Eikrem W (2007) Revisiting the nomenclature of haptophytes. Phycologia 46:471-475

Simon N, Cras AL, Foulon E, Lemée R (2009) Diversity and evolution of marine phytoplankton. C R Biol 332:159-170

Six C, Thomas JC, Brahamsha B, Lemoine Y, Partensky F (2004) Photophysiology of the marine cyanobacterium Synechococcus sp. WH8102, a new model organism. Aquat Microb Ecol 35:17-29

Six C, Finkel ZV, Rodriguez F, Marie D, Partensky F, Campbell DA (2008) Contrasting photoacclimation costs in ecotypes of the marine eukaryotic picoplankter Ostreococcus. Limnol Oceanogr 53:255-265

Six C, Sherrard R, Lionard M, Roy S, Campbell DA (2009) Photosystem II and pigment dynamics among ecotypes of the green alga Ostreococcus. Plant Physiol 151:379-390

Sournia A (1978) Monographs on oceanographic methodology: phytoplankton manual. UNESCO, Paris

Stauber JL, Jeffrey SW (1988) Photosynthetic pigments in 51 species of marine diatoms. J Phycol 24:158-172

Stolte W, Kraay GW, Noordeloos AAM, Riegman R (2000) Genetic and physiological variation in pigment composition of Emiliania huxleyi (Prymnesiophyceae) and the potential use of its pigment ratios as a quantitative physiological marker. J Phycol 36:529-539

van Leeuwe MA, Stefels J (1998) Effects of iron and light stress on the biochemical composition of Antarctic Phaeocystis sp. (Prymnesiophyceae). II. Pigment composition. J Phycol 34:496-503

Editorial responsibility: Hans Heinrich Janssen, Oldendorf/Luhe, Germany
Vaulot D, Le Gall F, Marie D, Guillou L, Partensky F (2004) The Roscoff Culture Collection (RCC): a collection dedicated to marine picoplankton. Nova Hedwigia 79:49-70

> Wright SW, Thomas DP, Marchant HJ, Higgins HW, Mackey MD, Mackey DJ (1996) Analysis of phytoplankton of the Australian sector of the Southern Ocean: comparisons of microscopy and size frequency data with interpretations of pigment HPLC data using the 'CHEMTAX' matrix factorisation program. Mar Ecol Prog Ser $144: 285-298$

Zapata M (2005) Recent advances in pigment analysis as applied to picophytoplankton. Vie Milieu 55:233-248

Zapata M, Rodriguez F, Garrido JL (2000) Separation of chlorophylls and carotenoids from marine phytoplankton: a new HPLC method using a reversed phase C-8 column and pyridine-containing mobile phases. Mar Ecol Prog Ser 195:29-45

Zapata M, Edvardsen B, Rodriguez F, Maestro MA, Garrido JL (2001) Chlorophyll $C_{2}$ monogalactosyldiacylglyceride ester (chl $C_{2}$-MGDG). A novel marker pigment for Chrysochromulina species (Haptophyta). Mar Ecol Prog Ser 219: 85-98

Zapata M, Jeffrey SW, Wright SW, Rodriguez F, Garrido JL, Clementson L (2004) Photosynthetic pigments in 37 species (65 strains) of Haptophyta: implications for oceanography and chemotaxonomy. Mar Ecol Prog Ser 270:83-102

Zapata M, Garrido JL, Jeffrey SW (2006) Chlorophyll c pigments: current status. In: Grimm B, Porra RJ, Rüdiger W, Scheer H (eds) Chlorophylls and bacteriochlorophylls: biochemistry, biophysics, functions and applications. Springer, Dordrecht, p 39-53

Submitted: August 27, 2010; Accepted: December 23, 2010 Proofs received from author(s): March 4, 2011 